\title{
Learners' Starting Age of Learning EFL and Use of Language Learning Strategies
}

\author{
Karim Sadeghi ${ }^{1} \&$ Zainab Abolfazli Khonbi ${ }^{1}$ \\ ${ }^{1}$ Department of English Language and Literature, Urmia University, Iran \\ Correspondence: Karim Sadeghi, Department of English Language and Literature, Urmia University, Urmia165, \\ Iran. E-mail: k.sadeghi@urmia.ac.ir
}

Received: September 26, 2012 Accepted: October 28, 2012 Online Published: December 12, 2012

doi:10.5539/elt.v6n1p28 URL: http://dx.doi.org/10.5539/elt.v6n1p28

\begin{abstract}
This study investigated the use of language learning strategies (LLS) and reasons for learning English among Iranian EFL students who began learning English at different ages. The participants $(\mathrm{N}=33$, both male and female) were divided into two groups of younger beginners (who began learning English before age 9; $\mathrm{N}=16$ ) and older beginners (who began learning English at or after age 12; $\mathrm{N}=17$ ). They were invited to complete Oxford's (1990) Strategy Inventory for Language Learning (SILL) questionnaire and to take part in a structured interview. While the students' choices of LLS were identified both through the questionnaire and interviews, their reasons for strategy use and their goals in learning English were determined using the interviews alone. Data analysis indicated that there were differences in LLS categories employed by the groups. Further findings and implications are discussed in the paper.
\end{abstract}

Keywords: language learning strategies, Iranian EFL learners, strategy training, starting age of learning

\section{Introduction}

Despite "the younger, the better" belief, the critical period hypothesis in second language acquisition is not fully supported by empirical research in many countries. Research into the age factor in second language acquisition can offer some insights into an early start in second language learning. Results in a study conducted by Snow (1983) show that starting age has an effect on the rate of acquisition and the ultimate level of achievement.

As far as the differences between adult and child language acquisition is concerned, Singleton (1995) stated that there are different views regarding the age issue, including the belief that children are in all aspects more efficient and effective second language learners than adults and that adolescents and adults are in all aspects more efficient and effective second language learners than children. The issue of whether effective adult L2 learners use similar learning strategies as effective child L2 learners has also attracted the attention of researchers. Chamot (1987) found that effective second language learners did use a lot of metacognitive and social/affective strategies. Accordingly, training on the use of metacognitive and social/affective strategies has seemed to be important for success in planning a language course.

Nunan (1999) for example, conducted a research study on the effect of strategy training on a group of university students in Hong Kong and found that the incorporation of a learning strategy dimension into the curriculum helped to maintain or enhance their motivation in learning English and that strategy training could help learners become more aware of the learning process. However, not much research seems to have been carried out on the differential use of learning strategies by young second language learners and in effect none of the relationship between starting age of learning EFL and the use of LLS.

According to Oxford (2001), learning strategies are the mental and conscious steps or actions taken by learners to facilitate a task, make learning faster, more enjoyable, more self-directed, more effective, and more transferable to new situations. They are also techniques, procedures, or operations employed by learners to aid the acquisition, storage, retrieval, and use of information for the purpose of becoming more proficient language learners (Cohen, 1998; Wenden, 1991; Nunan, 1999; Oxford, 1990; Chamot, 2001).

There are two sets of variables influencing outcomes in second language acquisition. One set includes variables relating to individual learner differences (e.g., age, attitude) and various kinds of situational and social factors (e.g., setting, target language). The other set includes variables related to learner's choice of language learning 
strategies. The relationship between these two sets of variables and the learning outcomes is that individual factors, together with social factors determine learner's choice of learning strategies. Learning strategies accordingly, influence the learning outcomes, i.e., the rate of acquisition and the level of achievement (Ellis, 1994).

This study was accordingly intended to find out whether students' starting ages in second language acquisition/learning influence the students' choice of language learning strategies, their goals in and reasons for learning English.

\section{Literature Review}

Learning strategies are seen as particularly important in the enhancement of learner autonomy because the use or adaption of appropriate strategies allows learners to take more responsibility for their own learning (Dickinson, 1987). Language Learning Strategies (LLS) have been investigated from different perspectives. Studies in this realm have usually investigated different aspects of learning strategies as perceived by teachers and by learners.

In Oxford (1990), a distinction is made between direct and indirect strategies. The former consist of "strategies that directly involve the target language" in the sense that they "require mental processing of the language" (p. 37), while the latter "provide indirect support for language learning through focusing, planning, evaluating, seeking opportunities, controlling anxiety, increasing cooperation and empathy, and other means" (p. 151). Direct strategies involve memory, cognitive, and compensation strategies and indirect strategies include three subcategories of metacognitive, affective, and social strategies. Each subcategory is broken down into two further levels. For example, one type of cognitive strategy is 'practicing', which consists of five different kinds of behavior (repeating, formally practicing, recognizing and using formulas, recombining, and practicing naturalistically).

Brown (1980) draws a clear distinction between learning strategies and communication strategies on the grounds that "communication is the output modality and learning is the input modality" (p. 65). Brown suggests that, while a learner generally applies the same fundamental strategies (such as role transference) used in learning a language to communicate in that language, there are other communication strategies such as avoidance or message abandonment which do not result in learning. Brown (1980, p. 118) concedes, however, that "in the arena of linguistic interaction, it is sometimes difficult ... to distinguish between the two" (cited in Griffiths, 2004, p. 47).

Most studies in the field of language learning strategies have tried to illustrate the effect of different factors on the choice and use of LLS. A good review of these factors by Oxford (1989) shows the following variables as relevant: language being learned; level of language learning, proficiency, or course; degree of metacognitive awareness; sex; affective variables such as attitudes, motivation, and language learning goals; specific personality traits; overall personality types; learning style; career orientation or field of specialization; national origin; aptitude; language teaching methods; task requirements; type of strategy training; and age.

As Oxford and Nyikos (1989) note, many of these factors such as language learning level, national origin, field of specialization, and language teaching methods have definitely been shown to be strongly related to language learners' choice of strategies, but others such as age, motivation, and sex have until now not received enough research attention to lead to firm conclusions.

Young children have been observed to employ strategies in a task-specific manner, while older children and adults make use of generalized strategies, which they employ more flexibly (Ellis, 1994). Young children's strategies are often simple, while mature learners' strategies are more sophisticated and complex. Chamot, Kupper, and Impink-Hernandez (1998) asserted that high proficiency learners know how to use appropriate strategies to reach their learning goals, while low proficiency learners are less expert in their strategy use and choice (Yang, 2007).

Oxford and Nyikos (1989) found that "motivation had a pervasive influence on the reported use of specific kinds of strategies, as well as on the degree of active involvement in language learning as reflected in the overall frequency of strategy use in general" (p. 97). Learners in second language learning environments were found to use strategies more frequently than those in foreign language learning situations (Green \& Oxford, 1995; Oh, 1992).

Reiss (1985), studying college learners at elementary and intermediate levels, found that "monitoring" and "attending to form" came out as the most common strategies used by learners whom teachers picked out as "good" (p. 88). Related to studies of "successful language learners' strategies" is the assumption that once the strategies of good language learners are identified, they can be made available, and where useful, used by less 
successful learners to enable them to learn a foreign/ second language more effectively (Hosenfeld, 1979).

To contribute to the field of research into the influence of age on students' choice of LLS, this research sought to find an answer to the following research question:

What are the Iranian EFL younger-beginner and older beginner learners' choices of language learning strategies, goals in, and reasons for learning English?

\section{Method}

The present research aimed to explore the use of LLS by Iranian EFL learners who began learning English at different ages. It was hypothesized that there would be differences in the choice of LLS and the learners' goals in and reasons for language learning between younger and older beginners.

\subsection{Design and Participants}

This study is a qualitative comparative study of the strategies used by Iranian EFL learners who began learning English at different ages.

The participants of this study were 33 Iranian EFL learners (12 males and 21 females) who studied English at a language institute in Hamedan, Iran. They were native speakers of Persian and were at the intermediate level. They were divided into two groups based on their starting ages in learning English. The younger beginners (group $\mathrm{A}, \mathrm{N}=16$ ) were those who started learning English before age 9 and the older beginners (group $\mathrm{B}, \mathrm{N}=$ 17) were those who started learning English at or after age 12. Age 12 has traditionally been taken as the end point of the critical period of language learning (Singleton, 1995).

\subsection{Instruments and Procedure}

All the participants were given Oxford's (1990) Strategy Inventory for Language Learning (SILL), version 7.0, to measure their choice of strategy. This version, including 50 statements, is utilized for the learners of English as a foreign language. The SILL asks students to identify the strategies that make the students to react to a series of strategy descriptions, such as, "I use new English words in a sentence so I can remember them". It uses a 5-point Likert scale from never true of me, to usually not true of me, somewhat true of me, usually true of me, and always true of me. It has six subcategories of LLS: memory, cognitive, compensation, metacognitive, affective, and social strategies. In this study, the alpha reliability of SILL was estimated at .76 which was above its acceptable value of 70 .

After the questionnaire survey, ten participants ( 2 males, 8 females) attended structured interviews designed to provide more in-depth information on the students' choice of LLS, reasons for their use of LLS and their goals in learning English as well. There were fifteen guiding questions in each interview. Questions 1-4 aimed at tapping the participants' personal goals in learning English, questions 5 to 12, focused on the participants' choice of the use of language learning strategies, and questions 13 to 15 , were meant to find out the participants' reasons for their strategy choice. The participants were asked to describe in detail when and why they started using specific language learning strategies. The ten participants were all volunteers, five from each group. The interviews were conducted individually, in Persian, and lasted for 10 to 15 minutes.

\subsection{Data Analysis}

The responses to the SILL questionnaire as well as the ten participants' responses to the fifteen questions in the interviews were content analyzed to elicit information for each category of strategy. Then responses from the two groups of participants were compared to find out if there were any differences between the two groups' choices of the use of language learning strategies. When analyzing interviews, particular focus was also put on investigating the participants' goals in learning English and their reasons for their choice of strategy use.

\section{Results}

The data collected from the SILL and the structured interviews were analyzed qualitatively as is now described. Based on the questionnaire, it was found that both the younger and the older beginners used compensation strategies the most as compared to their use of other groups of language learning strategies. On the other hand, the younger beginners used memory strategies the least compared to their use of other groups of language learning strategies. The older beginners used social strategies the least compared to their use of other groups of language learning strategies.

The participants' responses to the fifteen questions in the interviews, using Language Learning Strategy System (LLSS) developed by Oxford (1990, p. 18-21), were put under two classes, six groups, and nineteen sets of LLS (Table 1). 
Table 1. Oxford's strategy classification system (Adopted from Ehrman \& Oxford, 1990, p. 159)

\begin{tabular}{|c|c|}
\hline MEMORY STRATEGIES & $\begin{array}{ll}- & \text { Creating mental linkages } \\
- & \text { Applying images and sounds } \\
- & \text { Reviewing well } \\
- & \text { Employing action }\end{array}$ \\
\hline COGNITIVE & $\circ \quad$ Practicing \\
\hline STRATEGIES & $\begin{array}{l}\bigcirc \quad \text { Receiving and sending messages } \\
\circ \text { Analyzing and reasoning } \\
\circ \quad \text { Creating structure for input and } \\
\text { output }\end{array}$ \\
\hline $\begin{array}{l}\text { COMPENSATION } \\
\text { STRATEGIES }\end{array}$ & $\begin{array}{l}\text { - Guessing intelligently } \\
\text { - Overcoming limitations in } \\
\text { speaking and writing }\end{array}$ \\
\hline $\begin{array}{l}\text { META-COGNITIVE } \\
\text { STRATEGIES }\end{array}$ & $\begin{array}{l}\circ \quad \text { Centering your learning } \\
\circ \quad \text { Arranging and planning your } \\
\text { learning }\end{array}$ \\
\hline $\begin{array}{l}\text { AFFECTIVE } \\
\text { STRATEGIES }\end{array}$ & $\begin{array}{ll}\circ & \text { Evaluating your learning } \\
\bullet & \text { Lowering your anxiety } \\
- & \text { Encouraging yourself } \\
- & \text { Taking your emotional temperature }\end{array}$ \\
\hline SOCIAL STRATEGIES & $\begin{array}{ll}\circ & \text { Asking questions } \\
\circ & \text { Cooperating with others } \\
\circ & \text { Empathizing with others } \\
\end{array}$ \\
\hline
\end{tabular}

Direct (memory, cognitive, and compensation) and indirect strategies (meta-cognitive, affective, and social) were the two classes of LLS strategies in Oxford's system. The two groups of participants reported a lot on their use of both direct and indirect strategies in the interviews. However, the younger beginners used more LLS than the older beginners.

Comparing the use of the six strategy groups, it was found that the two groups of participants did not have great differences in the use of four groups of strategies: memory, metacognitive, affective, and social strategies. Both used many metacognitive strategies, some memory strategies, and very few affective and social strategies. However, there were great differences in the use of two other groups of strategies: cognitive and compensation strategies. The younger beginners reported more on the use of cognitive strategies than the older beginners. The older beginners used more compensation strategies than the younger beginners. In other words, there were some but not great differences in the use of LLS groups by students with different starting ages.

More differences were found when the participants' use of LLS in the nineteen strategy sets and examples were evaluated. The responses from the two groups showed that although they all used many metacognitive strategies, the younger learners did not use as much arranging and planning as the older beginners did. However, the younger beginners evaluated their learning a lot more than the older beginners did through self-monitoring and self-evaluating. The participants' responses also indicated that the younger beginners did not use the memory strategy of applying linkages and sounds but the older beginners used imagery to learn vocabulary and pronunciation. The younger beginners used more cognitive strategies than the older beginners. Although both groups practiced through repeating, with sounds and writing systems formally and naturalistically, the younger beginners knew how to use different methods to receive and send messages, analyze and reason the learning materials, and create structure for input and output. There was also a great contrast in the use of compensation strategies by the two groups. The younger beginners used very little of this group of strategies. In fact there was only one response on the use of guessing intelligently to find out the meaning of unknown words. But the older beginners used more compensation strategies, including guessing intelligently to find out the meaning of unknown words as well as overcoming the limitations on speaking and writing.

The interviews also revealed that there were differences between the two groups in their reasons for their use of LLS. Both the younger and the older beginners used all the six groups of LLS, although they did not use the same set of learning strategies in each strategy group. For example, both the younger and the older beginners reported on using a lot of memory strategies like creating mental linkages but only one of the older beginners used applying linkages and sounds. There were no great differences between their reasons for the use of memory strategies. The younger beginners said that their teachers suggested that they use these strategies to gain improvement in learning English. But the older beginners did not express clearly if their teachers had inspired them on the use of the LLS.

Individual participants did not use some strategy groups. One of the younger beginners used only three groups of 
learning strategies: memory strategies, cognitive strategies, and metacognitive strategies. However, information regarding the reasons for this student's strategy choice was not available.

All the participants interviewed reported on their use of LLS in learning vocabulary. They all stated that knowing more English words was very important to gain success in learning English. However, there were differences between the two groups' choice of strategies in learning vocabulary. Although, all the participants in the two groups used the strategy of grouping which was one type of memory strategy, it was obvious that the younger beginners just followed the teachers' instructions and kept vocabulary books, without knowing why they had to do so. On the contrary, the older beginners were very practical and knew that they could help them in writing and examinations. Their responses reflected two typical types of Iranian EFL learners. One type was passive in the learning and the other type was examination-oriented.

The analyses also revealed that both the younger and the older beginners could apply the strategy of reviewing well, which was one kind of memory strategy. Obviously, the younger learners knew how to apply the cognitive and metacognitive strategies when they knew how to seek authentic opportunities like writing essays to practice the vocabulary items in context while the older beginners depended only on rote learning.

There was another common feature when the two groups' use of cognitive strategies was compared. The younger beginners made use of devises like the electronic dictionaries to help them find out the meanings of unknown words in Persian. However, the older beginners used devices like dictionaries very rarely. Even when they used it, they just looked up the phonetic symbols. To the older beginners, learning the pronunciation of words was obviously more important than finding their meanings. They also used metacognitive strategies like paying attention to help them learn the correct pronunciation from their teachers. This was a strategy which the younger beginners did not report any incidents of use at all. Both groups also revealed using phonetic symbols which was one type of cognitive strategy, to help them with pronunciation. It was obvious that phonetic symbols were not taught formally in Iran's schools. However, both the younger and older beginners who had learnt them felt that they were useful.

Other than electronic dictionaries, the younger beginners reported having used a lot of other electronic devices to create opportunities for authentic practice which included the use of cognitive and memory strategies. They watched DVD repeatedly. Two of the younger beginners explained that in this way they could enjoy the programme and practice English at the same time. Their choice of these kinds of cognitive strategies was not shared by the older beginners. They practiced in order to get a better result in examinations and their practice devices were generally pen and paper. It indicated that even with the same strategy group, the two groups of participants applied them in different modes and used different devices because they had different reasons for learning English.

Another contrast between the two groups of learners was their use of metacognitive strategies such as setting their own goals in learning English. The responses from the participants indicated that the younger beginners' goals were simpler and more straightforward than the older beginners' goals. However, it was obvious that the older beginners were very demanding on themselves and had a lot of pressure in learning a second language.

In general, the analysis of the interview seemed to suggest that there were a lot of differences in the choice of language learning strategies between the two groups of participants. It was obvious that the younger beginners used more types of language learning strategies than the older beginners. However, the older beginners were more practical and used more LLS to enhance English language learning.

As regards the participants' goals in learning English, from their responses, it seemed that the younger beginners were not as ambitious as the older beginners. Great differences were found between the two groups' goals in learning English. Although, neither of the groups thought that their English was good, the younger beginners had no intention to gain any improvement and just wanted to acquire the minimum standard. They wanted to have less pressure in learning. They did not want to suffer from failure so they did not set a high standard for themselves. However, the older beginners were completely different. They had great determination to succeed in learning English and could not tolerate their lack of competence in coping with tasks in English.

\section{Discussion}

The findings here support previous research (Snow, 1983) in that older learners are not less effective learners than younger learners. They state strongly that "the younger, the better" is only a myth about acquiring a second language, meaning that many people believe it but it is untrue. The observations also confirm the findings of Singleton (1995) in that an early start is neither necessary nor sufficient for one to acquire a native-like accent. In line with the findings of Lightbown and Spada, 1993, p. 42) "learners who began learning a second language at 
the primary school do not fare better in the long run than those who began in early adolescence. On the whole, there is no strong evidence to support "the younger, the better" belief and an early start in second language learning as far as the use of language learning strategies are concerned.

When the students' use of LLS was compared using the two broad classes of direct and indirect strategies, there were no great differences at all. The younger beginners seemed to use slightly more LLS than the older beginners.

When the students' uses of LLS in the six strategy groups were compared, there were some differences. The results indicated that the younger beginners used more cognitive strategies but fewer compensation strategies than the older beginners did.

When the students' use of LLS was compared based on strategy sets and examples, more differences between the two groups' use of LLS were revealed. The younger beginners used more LLS like evaluating their learning, using different methods to receive and send messages, analyzing and reasoning the learning materials, and creating structure for input and output. On the contrary, the older beginners used more LLS which included using imagery to learn vocabulary and pronunciation, paying attention during the lessons in order to learn correct pronunciation from their teachers, guessing intelligently to find out the meaning of unknown words, overcoming the limitations on speaking and writing, and arranging and planning their learning.

The 33 students' responses in the SILL and the ten students' interviews both provided evidence regarding differences in the two groups' choices of LLS. The results in the SILL showed that there was no difference between the choices of LLS by students who began learning English at different ages. However, evaluation of the participants' responses in the interviews showed that there were many differences between the two groups' strategy choice, and particularly the reasons for their strategy choice.

The above qualitative findings through SILL questionnaire and interviews indicated that there were differences between the uses of LLS by students who began learning English at different ages. However, one possible explanation for the different results in the SILL and the interviews was that the SILL evaluated students' use of LLS as a whole. In general, this research found that the broader the classification of the LLS, the less contrast there was between the two groups of students. However, the interviews allowed the students to describe in detail their use of LLS. Their responses provided useful data regarding their reasons for the use of LLS. One more possible explanation to the contrasting results in the SILL and interviews was related to the characteristics of the students who were interviewed. The ten students were all volunteers and their responses might have not well represented the use of LLS by students in the same group. Future research may enjoy quantitative analyses, for example, comparing the students' means of scores in SILL against the groups' means scores on interviews to help clarify this point.

Finally, it could be explained that the older beginners had had fewer years of learning time, so in order to catch up with the English standards in Iran, they could only work harder in order to prepare better for the examination. However, they were under great pressure and not as relaxed as the younger beginners who had no pressure in learning English at all. Therefore, students' starting age did influence their goals in learning English.

\section{Conclusion}

The results of the study seem to indicate that the individual language learner differences in terms of their starting age of second language learning did influence students' choices of LLS. Students who began learning English at different ages used different LLS because of their different goals in learning English. Those who began learning English at a younger age learnt English to communicate with foreigners but those who began learning English at an older age learnt English to get in to the universities. Therefore different LLS were adopted by the two groups of participants.

Some of the implications of this study would be: 1) LLS should be incorporated into language courses in order to provide learners with greater opportunities to make language learning an autonomous process; and 2) teachers should be able to develop teaching strategies that are compatible with their students' ways of learning.

The limitations this study suffered from may be the intervening variables not considered in the grouping of participants, their general education, strategies in learning other subjects, gender, proficiency levels, and first language backgrounds. These are factors that might influence students' conception and belief in learning a second language and eventually influence their choice of LLS. Another limitation was that LLS were identified through students' self-report which would be inaccurate if not reported truthfully. Finally, the small sample size probably restricts the generalizability of the results.

Some suggestions for further research may be that besides structured interviews, other possible methods could be 
introspective interviews, stimulated recalls, and think-aloud protocols. Further research is necessary to investigate if strategy training could be designed to cater for the needs and interests of students with different starting ages in learning English. This study could also be replicated in different contexts. Further research may include the role of other variables such as motivation, interest, and attitudes toward second language learning.

\section{References}

Brown, H. D. (1980). Principles and practices of language learning and teaching. Englewood Cliffs, NJ: Prentice Hall.

Chamot, A. U. (1987). The learning strategies of ESL students. In A. Wenden, \& J. Rubin (Eds.), Learner strategies in language learning (pp. 57-69). Prentice Hall: New Jersey.

Chamot, A. U. (2001). The role of learning strategies in second language acquisition. In M. P. Breen (Ed.), Learner contributions to language learning: New directions in research. UK: Pearson Education.

Chamot, A., Kupper, L., \& Impink-Hernandez, M. (1998). A Study of Learning Strategies in Foreign Language Instruction: findings of the Longitudinal Study. Meclean, Va.: Interstate Research Associates.

Cohen, A. D. (1998). Strategies in learning and using a second language. Cambridge: Cambridge University Press.

Dickinson, L. (1987). Self-instruction in language learning. Cambridge: Cambridge University Press.

Ehrman, M., \& Oxford, R. (1990). Adult language learning styles and strategies in an intensive training setting. Modern Language Journal, 74(3), 311-327. http://dx.doi.org/10.1111/j.1540-4781.1990.tb01069.x

Ellis, R. (1994). The study of second language acquisition. Oxford: Oxford University Press.

Green, J. M., \& Oxford, R. (1995). A closer look at learning strategies, L2 proficiency and gender. TESOL Quarterly, 29, 261-297. http://dx.doi.org/10.2307/3587625

Griffiths, C. (2004). Language Learning Strategies: Theory and research. Occasional, 1, 1-35.

Hosenfeld, C. (1979). Cindy: a learner in today's foreign language classroom. In W. Born. (Ed.), The foreign language learner in today's classroom environment. Middle bury, VT: Northeast Conference.

Lightbown, P., \& Spada, N. (1993). How languages are learned. UK: Oxford University Press.

Nunan, D. (1999). Second language teaching and learning. USA: Heinle \& Heinle Publishers.

Oh, L. (1992). Learning strategies used by university EFL students in Korea. Language Teaching, 1, 3-53.

Oxford, R., \& Nyikos, M. (1989).Variables affecting choice of language learning strategies by university $\begin{array}{llllll}\text { students. } & \text { The } & \text { 291-300. }\end{array}$ http://dx.doi.org/10.1111/j.1540-4781.1989.tb06367.x

Oxford, R. (1989). Use of language learning strategies: A synthesis of studies with implications for teacher training. System, 17, 235-247. http://dx.doi.org/10.1016/0346-251X(89)90036-5

Oxford, R. (1990). Language learning strategies: What every teacher should know. Rowley, Mass: Newbury House.

Oxford, R. (2001). Language learning strategies. In R. Carter, \& D. Nunan. (Eds.), The Cambridge guide to speakers of other languages (pp. 66-72). Cambridge: Cambridge University Press. http://dx.doi.org/10.1017/CBO9780511667206.025

Reiss, M. (1985). The good language learner: Another look. Canadian Modern Language Review, 41, 253-511.

Singleton, D. (1995). Introduction: A critical look at the critical period hypothesis in second language acquisition research. In D. Singleton, \& Z. Lengyel. (Eds.), The age factor in second language acquisition: A critical look at the critical period hypothesis (pp. 56-73). Clevedon: Multilingual Matters.

Snow, C. E. (1983). Age differences in second language acquisition: Research findings and folk psychology. In K. M. Bailey, M. H. Long, \& S. Peck (Eds.), Second Language Acquisition Studies (pp. 95-109). Rowley MA: Newbury.

Wenden, A. (1991). Learner strategies for learner autonomy. UK: Prentice Hall.

Yang, M. N. (2007). Language learning strategies for junior college students in Taiwan: Investigating ethnicity and proficiency. Asian EFL Journal, 9(2), 63-70. 